\title{
塗装技能士受験解説
}

[III]

竹内 健 =

\section{3-2. 静電塗装}

静電塗装は, 静電気によって塗料を帯電化 させて, 被塗物に付着させる方法である。

直接塗料を霧化するためには, 空気圧縮機 で行なうもの，円板を回転させ遠心力によっ て，噴霧化させるものなどがあり一定ではな いが，いずれにしても塗料自体に静電力を与 它てこれをさらに霧化させると同時に被叙物 に吸着させ塗装効率を高めて行くのである。

静電塗装にあっては, 直接手作業で行なら もののほかに，自動的に連続作業のでさるよ ラにして量産に適合させた方法もあり，それ ぞれの製品の特長に合わせた方法で塗装す る。

静電塗装に特ける電気力の利用では静電除 滴法を含めて次のような特長をもっている。

1. 自動塗装化により量産ができること。 コンベアー方式により，塗装作業の自 動化が静電塗装によって可能であるこ 之.

2. 人手が極めて少なくてすさこと。

自動化によって, 人力作業が極度に減 少できること.

3. 塗料の損失が少ないこと.

塗料を荷電し, 被塗物の側・裏面まで 同時に塗装し，オーバースプレーが少 なくなること・

4. 塗料の微粒化が静電気力でできること 塗料を帯電させて微粒化が自然にでき ること。
これらの特長がある反面，欠点もある。

1. 塗料扣よび溶剤，希釈剤(うすめ液) の選択を必要とすること。

塗料や溶剤, 希釈剤の電気的極性によ っては微粒化ができない。

2. 被塗物の形状（特に凹部）によっては 十分な塗装ができない。

被塗物のL型の凹部などは, 電気的に 弱い部分ができて塗料の付着が極めて 困難となる。

3. 速乾性塗料の塗装が難しいこと。 極めて乾桼の速いもの，ぬた二液形の 塗料などでは使用が難しいこと。

4. 電気絶縁性の場合は塗装が難しいこと 下塗などが絶縁帯となった場合は電気 的に特殊な装置をしないと塗装ができ にくいこと.

以上の点が上げられるが, 電気的な知識を もっていない場合は使用できないことになる し, 最近では電気的安全度も高くなっている とはいえ，やはり理論的な知識が不十分であ る場合は取扱いが難しい点もあるのである。

\section{3一3. はけ塗り}

はけ塗りは，簡単な工具による手作業で, しかも特殊な技術を必要としなくてもできる ものであるが，しかし上手な塗装をするには また極めてもずかしい塗装法でもあるといっ てよい.

はけ塗りに当っては, はけの種類と塗料の 種類とを十分に知って，これを正しく理解し 
てこそ始めて美しい塗膜が得られるるのであ る。このことは，はけの毛質や塗料の特性 (くせ）を適確に知ったときにのみできるの であって，次のような諸点に十分な注意をし なけれぱならない。

\section{3-3-1. 塗料の粘稠度に応じた毛質を選 ぶこと}

叙料が高粘度の場合では (油性叙料, カシ ュ一塗料, 漆など）毛弾力性がある馬毛, 豚毛，人毛などで毛先のある，毛タケ（毛の 長さ）短いものを選ばなければならない。

\section{3-3-2. 塗料の含みと毛タケを選択して 塗装する}

塗装する面積が広い場合は，はけの毛タケ が長く, はけの厚さの厚めのものを選ぶこと が作業能率る高めることになり，作業者も楽 であるのではけの形次ても十分な注意 をすることが大切である。

\section{3-3-3. はけの形}

はけには平形のもの，丸形のものなぞがあ り, 中でも平形のものが多く使われていてそ の柄の形も一定ではないが，一般に使われて いるものとして，筋違いばけ，寸胴ばけ，平 将けなどが主なるので市る。

\section{3-3-4. 粱り方}

はけ塗りは，塗料の種類によってもまを その塗料の特長によっても塗り方はそれぞれ 異なっていなければならない，速乾性の塗料 で, 乾燥塗膜の減少率が大きなるのは, 毛質 の軟かいるので 1 回の塗付量は多い目に，し かる手早く, 平たん塗ることが大切であ る。すた遅乾性である油性系の塗料を叙付す るとは，毛タケのあまり長くないるのを用 いそして乾燥までの時間内で, 縦横に十分 ならしてはけ目をそろえるように塗装するこ とが重要である。また長短のある被塗物で 注長手刀方向塗ることを忘れてはならない し，無理のない塗り方である。

以上のように，塗装には特長を生かした塗
り方の内容を早くつかみ, しかも十分な結果 を得るために，塗料をただ塗ればよいという 考えではなくぞのように塗ることが合理的 かをよく, しかも正しく, 早くつかむことが 大切である。この意味では，金属塗装をする 人は多くの欠点を持っていることを忘れては ならない。

\section{3-4. 浸漬塗り}

浸漬塗りは，ドブッケとる呼ばれている塗 装法で, 塗料タンク (塗料槽) に被塗物を浸 漬して塗装をする塗り方であって, 防錆塗装 や下塗あるいは小物などに広く利用されてい るものである。

この塗装法の特長は, 塗装の際に塗り残し が全くなく、きわめて塗りにくいるのにも塗 装できるし，しかも能率的である。しかし欠 点としては，上部には薄く下部には厚くしか あ塗料のたまりや流れを残すことである。

このような欠点を補い，そのう光比較的美 しい塗膜が得られる連続的な塗装法として は, 最近, 静電除滴法との併用が考えられて いる。

使用する塗料の粘稠度は低いもので除滴が でき易いようにし，しかも塗料中に混入しゃ すい塵を除くために，槽の内部に「フィルタ 一」を付けておくことも大切である。また塗 料は常に循環するように靦汼しなければなら ない。

さらに浸清塗装の発展的方法として, 水中 分散をさせたもので「エマルジョン」化した 塗料として（溶剤を含んでいないのでその毒 性も除かれ，火気にも安全である) 新らしい 合成樹脂塗料が誕生しているし, 最近, 電泳 塗装として, 塗料中に電極を挿入して, 一定 の電流を通し, 希望の膜厚を電着させるとい う方法も実現している。この方法によれば， 塗装後, 水洗して余分な叙料を除き，ベーキ ングによって美しい塗膜を得るようになり浸 漬塗装も上塗り塗装に使用できるようにな 
りつつある。

\section{3-5.ローラー塗り}

ローラー塗りは, 手作業で行なら簡単なも のと,ローラーコーティングのように機械化 させたものとがある. 前者は円筒形のものに 短毛を植えつけたものまたはスポンジをとり つけたものに塗料を含ませて，これを回転さ せながら被塗面に塗付する方法と，印刷機械 のように何本かのロールに塗料を巻き取るよ らにして被塗面に塗る方法とがある。

いずれも広範囲の面を塗装することと連続 的な塗装ができる特長をもっているが，塗面 に小さい凹凸（しぼ）ようのはだができる欠 点がある。

\section{3-6. ころがし塗り}

ころがし塗りは, 容器中に小形の被塗物を 投入して，これに少量の塗料を注入しつつ容 器を回転しながら塗装する方法で, ちょうど 医薬の外面の糖衣と同じょうな塗装法であっ て，小物の塗装には適した方法である。この 塗装では，一般の場合よりもかなり高い粘稠 度の叙料を加える方が良い塗装効果はむし ろ能率的でありまた回転に伴なって温度 の上年が見られるのも特長である。しかし塗 装中に高温になったため引炕したり金属どう しが触れるため，自然発火を生ずることるあ るので注意しなければならない。この種の塗 装法の応用としては引き妵り（鉛筆の塗 装法）などが上げられる。

\section{3-7. 流し塗り}

流し塗りは,ただ単に塗料を流して塗装す る方法と、これを機械的な連続作業としたも のとがある・その主なものは次のよ5なもの である・
1. カーテンコーター
2.フローューター

3. 流し塗り

\section{3ー7ー1. カーテンコーター}

カーテンコーターは, 平行させた 2 枚の厭
味のある精密な金属板の狭い間から整料に圧 力をか惊て塗料を幕のように，あるいは滝の ように流出し，この間をくぐるように通過さ せて塗装する方法であって, 連続的に一定の 幅のある平らなるのを塗装するのに適した塗 装法である。叙料の落下には，塗料の粘䅕度 と圧力とに特に注意すると同時に，被塗物の 送り速度も塗膜厚ならびに塗膜中に気泡を発 生させる原因ともなるので，十分に注意して 操作しなければならない。

原理としては，ちょうど滝の中を通るよう なもので，簡単ではあるが，被塗物の形状や 㓌料の性質によってはピンホール（針穴状） の発生などもあるので注意すること㔔大切で ある。

\section{3ー7-2. フローコーター}

フローコーターは，噴霧塗装の項で若干触 れておいたが，塗料ノズルから噴出する塗料

（加压して散布する）の中を被塗物を通過さ せて余分の塗料を滴下させる方法で，浸漬塗 装に良く似ている塗装法である。

塗料は比較的粗らい霧の中を通って，余分 に付着したものは流出・滴下して乾燥するの であるから，塗膜の美的な面よりも早く塗装 することの効果をねらったものである。

\section{3-7-3. 流し塗り}

ばけやへらを用いて塗る操作を変化させた もので，被塗物の平らなるのを塗装する方法 の 1 種である. 主としてポリエステルの塗装 にはかなり広く使われているもので, 被塗物 に一定量の塗㳆を流し, 平均に流展するよう にしたものである。

\section{3-8. へら塗り}

へら塗りは，下地途料を用いる場合や塗料 を配るために使われる方法で，塗料の種類や へらの性質によって色々の方法が取り入れら れている.この塗装法は難かしく，極めて熟 練堂必要とする䇗り方であって，使われる工

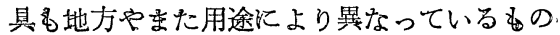


でそその主なるのは次のようなるのである。

1. 木べら：ひの木, もみじ, つげ, 水なら やなぎ等

2. 金ベら：4.5炭素鋼(半鋼鉄をたは鋼鉄)

3. ゴムベら：耐油性ゴム

普通使われるすのでは，木べらが最る基 本的なものとなっていて，1枚の板材(割木) を用途飞応じた幅として，これを斜めに切り 離し, 先を平らにまたは丸形として, 被塗物 飞合わせてへらの腰を削り出し，材料(下地） の硬さにも合わせて塗り付けるのである。

へらの腰は, へらの材料と用いる塗料に応 じてその強さを調節するのであって，木べら の特長とするところは, 腰の強さを自由に調 節しやすいことにある. 金べらは，これと全 く反対で西って腰が一般に硬く, へら先が損 じないことと，平らな面をへら塗りするのに 適しているものである.ゴムべらは, 最も腰 に弾力性があり，被塗物の形によってはその 自由性が利点となって扔り, 凹凸に応じて叙 装できる特長を持っている。

このように，へら塗りは各種のへらを使っ て，主として下地塗料を塗装するのに利用さ れるが，粘稠度の高い塗料を塗装する際には 塗料をへらで配るかまたはそのまま塗装した り，あるいは特殊な塗装としてへらを利用し て，シボ立て（特別な凹円）をするときにる 使われる。

下地塗装飞際しては，パテばけとして下地 を配り，次にこ机を「ならし」，さらに仕上

「きめる」をするのが普通であって，その操 作には極めて熟練を必要とするし, 塗料の特 長によっては短時間で仕上げる方法によらな ければならない。また機械でへら塗りをする 方法子あり, この場合は, 緃形の刃先のある ものでカットするようにして一定の塗装がで きるように被塗物を送って下地付けをする。 しかし, このょうな機械は特殊な場合以外は 使用できないので一般的ではない。

\section{3ー9. ステンシル塗装}

ステンシル塗装を一般の塗装法としてここ で上げることについては多少の問題がある が，本基準では，一般の塗装法の中に記載さ れているのでここで示すこととする.

ステンシル塗装は，一般には塗り分けて模 様や図案, 絵画などを塗装しながら構成して 行く方法で，塗装する場合は，吹付け塗り， はけ塗り，ブラッシュによる塗付，へらしご き塗りなどが利用される. 塗り分けでは粘着 テープ (マスキングテープ) やマスク, 形紙 などが使われるが，いずれにしても塗装に当 って，地塗りして仕上げた面に実施する場合 と，下塗りのとさに模様づけをしてさらにそ の上飞透明な塗料 (ワニス) を塗装して平滑 な塗装仕上げとする場合とがあり，むしろ施 工の方法としては特殊叙装として, 室内の装 飾をはじめ, 製品のマーク, 玩具塗装, 塗り 分けなどに広く応用されている塗装法であ る。

以上のように，塗り方には色々の方法があ り，塗膜を形成する場合に，塗料をどのよう な方法で被叙物の表面に塗り拡げるかであっ て，比較的飞簡単で，被塗物淛限されない 方法は，か无って古来からある原始的な塗装 法でよいが，機械力を使った場合には，塗装 する条件が一定でなければならない。るちろ ん塗装法なるものは日進月歩で，いわゆる新 らしい塗装法は, 塗料の変化, 高分子化学の 発達に伴なって変化するであるうし, その利 用価值も日增しに多くなってくるもので，今 後は粉末の塗装や，ゲル状（寒天状態）のも のを押し拡げて一定の条件で処理する塗装法 などもできてきて，ますます塗装の分野は新 らしい段階発展する可能性を内抱している あのであるといってよいだろう。これらに対 态して塗り方に特いても，技能や知識を十分

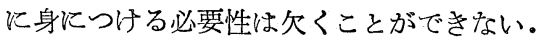

\section{4. 特殊塗装法}


特殊塗装法は, 基準では主な特長について 知っていることと規定している。その中で上 げられているものは次のょろなものである.

1・メタリック塗装

2. ハンマートン塗装

3. ちりめん塗装

4. 結晶塗装

5. クラッキング塗装

6. スチップル塗装

7. 木目塗装特よび石目塗装

8. 梨地塗装

9. 水玉塗装

10. 彩色塗装

11. フロック塗装

12. パール塗装

以上の 12 種であって， 2 級の場合は $1 \sim 5$ までとその範囲が狭いのである。

以上に記載されているとれぞれの塗り方 は，主として塗料によってなされるるのと， 全く塗料は一般のるのと変わらないが，施工 法によって特殊な塗装をするものとがあり， 本規準で特に分けていないのであるが，これ を二つに分けて本項で説明する方が理解しや すいのではないかと考觉るので，分けて説明 をする。

\section{4一1．塗装法による変り塗り}

塗料に関係なく，ただ塗装技法によって塗 膜に変化をあた觉るもので，次のよ5なるの が上げられる。

1. スチップル塗装（コンビネーション塗 装)

2. 木目塗装招よび石目塗装

3. 梨地塗装

4. 水玉塗装(光り塗り,シャボン玉塗り)

5. フロック塗装

ここに上げている各種の塗装法は，それぞ れ一種ではなく，打の抢のの塗装にも何種類 かの塗装の施工方法があるのであって, 技術 者の持っている技術の程度と忍用力によって
も先の持ち味の異なった美しい塗装を創造す ることができるのである。

\section{4-1ー1. スチップル塗装}

スチップル塗装には， コンビネーション塗 装, さめ皮塗り,たたき塗りなぞの各種の名 称とそそれぞれの塗装法がある。

この塗装法は，塗面に凹凸を作って塗面の 陰影炕よて，軟かい感じと深味をあたえる るのである。

一般に高級な機械, 器其, 試験機などと応 用され特殊な塗装効果をあたえるるので，金 属素地の上飞防錆塗装や下・中塗りの塗装を し,さらにその上に下地塗料や, 高粘稠度の 塗料をへらやタンポ，金ぐしなぞを使って色 々の膜様を作るものである.

下地塗料としては, 各種下地塗料あるいは 体質顔料にワニスを加えて作ったすのなど塗 料の流動性を少なくした各種のものを用いて 「シボ」立てをするのである。さらにこの上 飞地塗りをするかまたは地塗りの乾燥後凸部 の表面に異なった色を持つ塗料で彩色を行な って変化をあたえるのである.この棌か「シ ボ」の表面を研削して凸部の頭を平らにして 変化をあたえたり，キルク原，ノコ屑などを 応用したものるある。

この際「シボ」立ての塗料詨して中・上 塗り怙よび彩色の塗料の性質を十分飞考えて 塗装しなければならない。

\section{4-1-2. 木目塗装および石目塗装}

木目塗装特よび石目塗装には, 色々の方法 があり，一定していないが，木目塗装は金属 にはない木材の美しさを表現するもので，木 目として各種の銘木の最も美しい木目をま た石材としては大理石, 瑪瑠（めのう）など の美しい石目を作るもので，その方法には多 くのものがある。

a 、転写法：木材の木目の金属板への転 写

b. 転写紙法：転写紌の塗面への転写特 
上び張りつけ

c . ローラーがき法：ローラーによる木 目の転写

d．木目の手がき法：はけ類による手が き

e . 石目がき法：真綿枠による石目模様 がき

\section{a 、転写法}

転写法は美しい木材の原木を平らに削り， これとその面の木目中に目止剤を良く充てん したものを耐油性ローラーか膠ローラーに写 乙取り，これを金属板に写し出す方法であ る.長いものはローラーの直径を大きくすれ ば良いが，木目が色では何か不自然な面がで きるので, この場合は地塗りの色や木目の色 彩を考慮することによって美しい塗面の仕上 げが得られる．もちろん転写後，上塗りにワ ニスによる透明仕上げを十分に行なわなけれ ばならない。

b 、転写絓特よび印刷紙張り法

最近の印刷技術の向上で，良質の転写紙や 印刷紙があり，これを下叙りの上飞転写する かあるいは張ることによって，美しい木目を 得ることができるようになった。

この場合，転写紙の方は，地叙りを実施し た上に，木目のある転写紙を水張りして木目 を写し取るものであり，紙張りの方は，防錆 塗装後，合成樹脂の接着剤で䋊張りし，その 上にいずれの場合も透明塗料 (ワニス) を塗 装して仕上げるのである. 前者は最近では利 用率が少ないが，後者は印刷も色刷りで美し いものがあるので，多量飞使用されている。

\section{c、ローラーがき}

ローラーがきは，耐油性のゴムローラーに 年輪を掘りつけ, これを薄く下叙塗装をした 面の乾きかげんの良いときに当てがいずらし つン回転しながら塗りつけるのであるまた 金属板の「ギヤ」状のギャの間隔の異なった
ものを重ねたローラーで，柾目・木目を觉が く方法などがあるが，いずれる平滑なものに 対しては比較的簡単に木目模様が得られるの が特長である。

\section{d。木目手分き法}

手がき法は，木目ばけ，ブラッシュ、ゴム ばけなど各種のもので手がきをするのである が,この方法は全く技術的なるのであって, 一般のはけや木目用の特殊なはけを用い木目 の美しい模様を手がきする方法である。

特殊な木目ばけとしてほ，豚毛の毛タケ 10 18 cm の長いしか子極めて薄手のはけを 作り、これをあらかじめ遅乾性の塗料を薄く 塗布したるのの上を引きながら塗装するか， または押すよろにして毛の弾性を利用して， 木目をえがくのである。この場合の木目がき は，木材の美しい木目を良く観察して兄がく ことが大切で，木目の生きたえがき方をする のには，極めて熟練を必要とするので十分に 研究することが大切である。

はけの毛質は，硬・軟いずれる自由で，そ のはけの特性に応じてえがかれれば，木材の 各材質の美しい木目のものが得られるのであ る。

\section{e 。石目塗装}

石目塗りは, 大理石のような美しい模様を 得るので, その模様によって色々のものが使 われるが，これには木枠滇綿を引いて張り つけ，それを基本にして美しい樣模を作ると か，「ふのり」日本紙などのあのを枠張りし て使うのであって, 形と色彩とが織り出す美 くしさが石目となるのである。

いずれにしても自然にある美しい石材の模 様を実際の塗膜で表現するためには，それに 応じたるのを利用するので, 石目塗装だけで なく木目塗装またはそのほかのすのでも色々 と使われるのである。

\section{4-1-3. 梨地塗装}

梨地塗装は, 漆塗りの梨地塗りから発生し 
たもので, 漆器の梨地塗りの奥深い美しさが 生かされたものである. 本来の梨地塗りは, 金，銀の梨地粉を溙の乾燥を待たずに蒔き付 けその上に梨地漆を塗り重ね，研き仕上げを して得るもので, 平目塗りも全く同じ手法で あるので一般には混同されている。

漆塗り以外では，吹付けによるものがあ り, 地塗り仕上げしたものの上に, 金粉（真 鍮粉)，銅粉，アルミニウム粉を薄く塗付し (ワニス中に混合して), 未乾燥の上に溶剤 を吹付ける方法と, 地塗り後, 金, 銀粉など を低圧で粒子を大きくして吹付ける方法とが ある.いずれも吹付け後，上にワニスを塗っ て仕上げるのである。

\section{4-1-4. 水玉塗装}

水玉塗装は, 吹付けに際してきわめて近距 離にスプレーガンを近づけて吹付ける方法で 吹きつけられた塗料が，空気の圧力で円形に 広げられた模様が水玉状になるためである。 この方法は，1色だけでなく，地色と上塗り との関係や水玉の色によって，また平列にす る場合と重福る場合とによって全く味合いの 異なった模様となって美しいものとなる。こ の塗り方の利用は, 什器, 玩具, 文房其など に広く使われているもので個性のある塗装法 の 1 種である.色彩の配合や模様のバランス が良ければ大変美しいものとなるが，特に熟 練を必要としない良い面もある。

\section{4-1-5. フロック塗装}

フロック塗装は, 遅乾性の塗料の塗付後, 短毛の羊毛, 紙繊維, 微粉などを吹付ける方 法で, 塗面の軟かい感じならびに吸音効果と 断熱性の効果のあるものとなる.乙か子基本 的には蒔絵の原理を応用したもので, 平らで なく, 手ざわりの良い塗装法の一種である.

以上のような特殊塗装法は, 特殊なものを 除いては，いかに利用するかという点で十分 研究され，設計と実際の使用目的を十分に考 慮した上で最も美しい塗膜を得ることに努力
しなければならない。

\section{4一2. 塗料における特殊塗装法}

塗膜に変化をあたえて美しい塗装をする手 段として，塗装技法によるものはすでに記し たが，塗料によるものとしては，塗装方法に ついてももちろん注意しなければならない がむしろ塗料の特性を十分に出せるよう に，塗り方についても注意を必要ともるので あって，塗料に見合う条件をできるだけそろ えるために, 温度や操作を塗付量・処理法の 適切な方法とすることにある。

一般にこのような塗装法には，次のような ものが上げられている。
1.メタリック塗装
2. ハンマートン塗装
3. らりめん塗装
4. 結晶塗装
5. クラッキング塗装
6. 多彩塗装
7. パール塗装

\section{4-2-1・メタリック塗装}

メタリック塗装は, エナメルまたはワニス の中に銀粉 (アルミニウム粉) を混合・分散 したもので，特長は光が銀粉によって反射し て深味のある美しさが得られるのである.こ の銀粉は，塗膜の表面に浮いて出ないように 作られているので, ノンルーフィングと呼ば れ，一般には二トロセルロース系（ラッカー 系）のものと，アミノアルキド樹脂塗料など が主に使われているものである.

塗装に沶いて塗膜に若干の流れや「さら」 が生ずると, 普通のエナメルの場合よりも明 りょうに現われるので特に注意しなければな らない.このために, 塗料を薄めすぎないこ とと, 吹き付けるときに少し遠い目にして吹 き付けるのがよい。

\section{4-2-2. ハンマートン錭装}

ハンマートン塗装は, 桘目塗装などと呼ば れる塗装法で, 板金加工の打出し, 絞り加工 
の槌の跡の美しい模様に良く似ているので, この名称がある.塗料は，アルキド樹脂系の もので, 乾燥の過程で模様が出るように特殊 の製造方法をとっているもので，ハンマート ンは,メタリック塗装と同じく銀粉を混入し てょり美しくしている.塗料には，常温乾燥 形々焼付形と 2 種があり，最近では両者兼用 のものも販売されている.

用途としては, 電気器具, 機械類, 測定機 器などに主として使われているもので，防錆 塗装や下塗りの上飞塗付するのである. 塗り 方としては，次のような諸点に注意するとよ w.

1. 塗料をうすめすぎないこと。

2. 若干厚目に塗装すること。

3. 吹き付け距離は少し遠目とすること。

4. 塗膜は平均に塗付すること.

5. 吹き付けの空気圧は高めにすること. 以上のよ 5 な点が大切であり, 塗装後に乾 燥するまでの間に流動性から塗膜となり，槌 目が自然に発生する間を予測して，塗付する 叙料量を調節するとよいまた縱面と平面 (垂直面と水平面)とでは,棺目の感じが異な って出やすいので，できれば水平面で吸き付 けると良い，また垂直面で塗装する場合は， 下塗り塗料北関係するので, 下叙り塗料の選 択も考えることが一つの条件といえる。

\section{4-2-3. ちりめん塗装}

らりめん塗装は，ちりめん状のしわを発生 する乾性油（支那種桐油）を配合して製造し た特殊㙦料で，細かい波状の凹凸が生ずる桐 油の特性を生かしたるのである。桐油は，共 範二重結合を持っている特殊な乾性油で, 特 定の条件をあたえるとしわが生ずるのであっ て，製品によって異なってはいるが，60〜 $80^{\circ} \mathrm{C} ， 20 \sim 30$ 分間加熱処理することによって 塗面にちりめん状の美しい凹凸を発生する。 これをさらに 120 210 ${ }^{\circ} \mathrm{C}$ て処理して硬化さ せる.ちりめん塗料に各色のものがあり，
このほが透明なワニスのる作られている。 また厚塗りをすると, ちりめんの模様は大 きく, 薄く塗装すると細か心模様となるが, 余り薄いと, ちりめん模様はでさないので注. 意しなければならない，また多量の溶剤を加 えたり, 低沸点の溶剤を使用すると, 条件飞 よってはちりめんを発生しない場合もあり， さらに急に高温としても美しい模様は得られ ないので，溶剤や熱処理には十分注意して招 くことが大切である. 特にボイル油なぞの混 入は，全く㙦料の特性を失ならことになるの で, 塗料の調合に当っては必要以上飞注意す るぐらいが良い。

\section{4-2-4. 結晶叙装}

結晶塗装は，支那種桐油の雪花現象を生ず る特性を利用したもので，生の支那桐油を急 激汇重合乾燥を行ならとこの模様を発生す る.

このような特殊な模様の発生はちりめん塗 料と全く同じであるが，ちりめんよりる模様 の発生は困難であって, 乾燥炉中でも雪花模 様を出させるためには燃暁ガスを直接塗面に 触れさせ，重合る促進させると美しい結晶模 様を得ることができるのである.

塗装法としては, ちりめん塗装と全く变わ らない。

\section{4-2-5. クラッキング塗装}

クラッキング塗装は, クラッキングラッカ 一 (硝化綿塗料) 々称している龟裂を発生す る塗料を用いて塗装する方法である。この塗 装は，顔料分分多いために，あらかじめ下塗 りしてある塗料の上に吸き付けまたはなんら かの方法で塗装すれば，下塗りと上塗りとの 間の乾燥のための収縮の違いによって龟裂が でき，この不規則な龟裂が作る模様が美しい ので使われている. もちろ几顔料分が極度に 多いために，被覆性はあっても塗膜強度がな いので，上塗りにはワニスを塗装して仕上げ るのである、塗装に扣いて厚塗りをすれば大 
きな龟裂ができ，薄く塗れば細かい亀裂を生 ずる.しかし下塗りと上叙りとの色彩が調和 していなければならないのであって，各色の 中から適当に製品烚った色調のるのを選ぶ べきである。

利用されるものとしては，小形の製品が多 く, 機械器具, 文房具, 日用品などに使われ ている.

\section{4-2-6. 多彩塗装}

多彩塗装は, 乱䋡塗り, マルテンカラーな ぞが上げられる。この種の塗料は，特殊な塗 料の性質を利用したものであって, 乱糸塗り は高分子の高粘稠度の樹脂（合成ゴム）を吸 き付けることによって，系を引いて不規則に ならべたような模様が得られるのである．色 彩は, 地塗りの色との調和と，また別に塗装 された同系の塗料との重なり具合などで変化 に富んだ美しさが求められる。

マルテンカラーは, 塗料の性質の異なった 2 種類のものを混合して大小のコロイド状に したものを懸垂状にした塗料で，特殊なスプ レーガンで吸き付けると色々の模様が得られ
るし，塗料は 2 種をたは 3 種というように色 々のものを混合して色彩の美しさを得るので ある。

\section{4-2-7. パール塗装}

パールとは真珠のことで, この塗装は模造 真珠をつくことから始められ，真珠の美し さが自然に一般の塗装に移されたものであ る. 古くは太刀魚(たちら呿)の鱗(らろこ) を粉末にしたるのを塗料に混合して塗装した のであるが，近年無機顔料 (特殊顔料) とし て優れたものができ，多量にこの種の塗装法 に利用されている、利用されているるのには 容器類, 交房具, 日用品, 工芸品などがあり 機械類としては測定機器などにも利用されて いる。

以上のように, 塗装法は広範であって筆で は畫くことが困難であり，実際にこれを示せ ば，考えるよりもはるかに理解しやすいので ある. 交章で一つの動作を分解して説明する のに，十分に表現しきれないのは技法のむず かしさでもある。

(つづく)

(千葉総合職業訓練所)
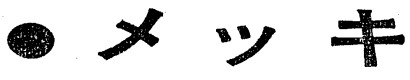

膜

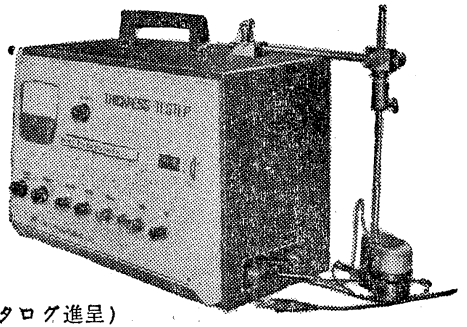

特許ベルトーロ・セレン・シリコン整流器/全自動・半自動鍍金荘置

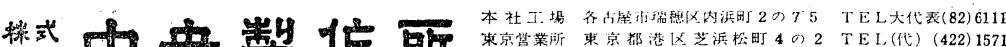
会社 